\title{
Tree dimension and environmental correlates of heartwood content in Siamese rosewood (Dalbergia cochinchinensis)
}

\author{
PONTHEP MEUNPONG ${ }^{1, \vartheta}$, CHATCHARIN PENBOON ${ }^{2}$, NAWAPHONG KUASAKUN ${ }^{3}$, \\ CHONGRAK WACHRINRAT ${ }^{1}$ \\ ${ }^{1}$ Department of Silviculture, Faculty of Forestry, Kasetsart University. 50 Ngamwongwan Rd, Chatuchak, Bangkok 10900, Thailand. \\ Tel.: +66-853-197912, `email: fforptm@ku.ac.th \\ ${ }^{2}$ Department of National Park, Wildlife and Plant Conservation. 61 Phahonyothin Rd, Chatuchak, Bangkok 10900, Thailand \\ ${ }^{3}$ Royal Forest Department. 61 Phahonyothin Rd, Chatuchak, Bangkok 10900, Thailand
}

Manuscript received: 3 April 2021. Revision accepted: 23 May 2021.

\begin{abstract}
Meunpong P, Penboon C, Kuasakun N, Wachrinrat C. 2021. Tree dimension and environmental correlates of heartwood content in Siamese rosewood (Dalbergia cochinchinensis). Biodiversitas 22: 3297-3303. Siamese rosewood (Dalbergia cochinchinensis) is considered amongst the prime timber varieties in high demand with the wood fetching high prices in the international timber market. Therefore, illegal logging and smuggling of Siamese rosewood from natural forests poses a severe problem in Thailand. Heartwood and its content is the most valuable part of Siamese rosewood, which in practice, cannot be measured directly in living trees. Hence, we investigated the relationship between the heartwood content of Siamese rosewood, and tree dimension and environmental characteristics across eleven plantations throughout Thailand construct a model for predicting the heartwood content using specific environmental variables. The results indicate that there were differences in the mean annual increment of all measurement parameters $\left(\mathrm{d}_{0}, \mathrm{~d}_{30}, \mathrm{dbh}, \mathrm{and}\right.$ total height of a tree) across eleven plantations studied. However, we did not find any statistically significant differences between the increments in heartwood diameter. Furthermore, we found that suitable location for Siamese rosewood plantation could result in doubling of growth rate. We report that dbh was the most relevant variable and could be used as a predictor for heartwood content. In terms of environmental variables, soil properties at top layer that affect the heartwood content were particle density, organic matter, and silt particles. Using the resulted equation formulated in this study may be useful when planning areas for suitable plantations of Siamese rosewood in Thailand.
\end{abstract}

Keywords: Dalbergia cochinchinensis, heartwood, hongmu, rosewood, Siamese rosewood

\section{INTRODUCTION}

Dalbergia cochinchinensis (also known as Siamese rosewood) is a slow-growing tree species with original distribution in Cambodia, Laos, Thailand, and Vietnam. Siamese rosewood is considered a "first-class prime timber" species as it is hard, durable, easy to work on, and resistant to insects (Xu 2016). Its timber is highly-priced with high demand in the international timber market, especially in China. For example, the Chinese market is experiencing an increase in demand for luxury wood furniture and cultural artworks rooted in Ming and Qing dynastic aesthetics made from premium wood (EIA 2014). China alone imported 1.96 million $\mathrm{m}^{3}$ of rosewood logs and sawn wood in the year 2014, which is an increase of $70 \%$ over the previous year and $1,250 \%$ since 2000 (Treanor 2015).

Because of its popularity, Siamese rosewood has been overexploited and is in the "vulnerable" category according to the International Union for the Conservation of Nature (IUCN) Red List (IUCN 2021). The Convention on International Trade in Endangered Species of Wild Fauna and Flora (CITES), which regulates international commercial trade, listed it in Appendix II insinuate that international trade is carefully regulated, and it might be approved by the issuance of an export permit or a re-export certificate (CITES 2014). The increasing rarity of such timber has led to dramatic price rise, resulting in a large number of Siamese rosewood trees being harvested illegally from natural forests and smuggled to other countries, as indicated by more than 5,500 criminal cases filed over the years (EIA 2014). Such figures indicate that the illegal cutting of trees for timber within the protected forest areas has increased greatly. As of 2005, 300,000 trees of Siamese rosewood reportedly remain in natural forests, with the number having recently reduced further to 100,000 trees (CITES 2013). Thailand continues to be targeted for illegal logging of rosewood (United Nations 2015).

As a response to illegal logging and to cater to an everincreasing demand for Siamese rosewood timber, plantations can play an important role in reviving this tree species and have been promoted in certain areas by the Thai government (Phunchaisri et al. 2020). However, a comprehensive understanding of the ecophysiology of wood, especially heartwood formation, in Siamese rosewood is not yet adequate to provide robust information for the development of its silvicultural practices. This knowledge is important since heartwood is the most valuable part of Siamese rosewood that determines the price of the timber. Unfortunately, knowledge and application of Siamese rosewood heartwood formation are 
limited due to the complex numerical information required. Therefore, the question of tree dimension and environmental conditions as correlates of heartwood content is addressed in this study.

Heartwood formation is a natural growth-regulating process related to the development of a tree and helps to maintain an optimum sapwood volume (Pande 2013). Heartwood and sapwood have different properties with their proportion within a stem having a significant effect on the rational utilization of timber. Heartwood normally determines the value of wood, while sapwood is closely correlated with the physiological functions of trees (Yang et al. 2020). Site differences in humidity, wind exposure, climatic region, altitude, and aspect are strongly related to the width of heartwood. The maximum value of heartwood to sapwood ratio occurred most frequently in the north direction while the minimum value occurred in south direction, reflecting the difference in the microsite (Liu et al. 2014). Moreover, silviculture practices can influence the formation of heartwood, such practices can significantly affect the quantity of heartwood, e.g., proper thinning and fertilization can promote stem growth and thus accelerate heartwood formation (Yang et al. 2020).

Nonetheless, the quantity and proportion of heartwood cannot be measured directly in living trees. Non-destructive measurement methods to measure heartwood are yet to be developed sufficiently to be used in providing information about the formation of heartwood. An accurate estimation of heartwood volume based on easily measurable tree variables is needed by plantation owners to determine the heartwood content that can be obtained from trees before they are logged. Therefore, the current study aimed to create a predictive model using easily measurable tree-level variables to predict the heartwood content of each tree and also to construct a model for predicting the heartwood content using specific environmental variables. The results of this study may be useful in monitoring and improving the quantity and quality of heartwood in Siamese rosewood plantations. The Siamese rosewood timber supplied from plantations can help in reducing illegal logging within conserved forests in Thailand.

\section{MATERIALS AND METHODS}

\section{Study area}

Investigations were conducted at eleven stands located in five different regions based on climatic characteristics (Inthacha 2011), as shown in Table 1 and Figure 1. The mean annual precipitation ranged between 788-4,468 mm, while $75 \%$ of the rainfall is concentrated during the months of July-October. The altitudes where these plantations are located ranged from 51-496 $\mathrm{m}$ above sea level. Stand age ranged between 17-53 years and the spacing ranged from 3 $\mathrm{m} \times 3 \mathrm{~m}$ to $6 \mathrm{~m} \times 6 \mathrm{~m}$.

In each stand, three square plots of 0.25 ha in size were randomly established, where all trees were measured for their diameter at ground level $\left(\mathrm{d}_{0}\right)$, diameter at $30 \mathrm{~cm}$ height $\left(\mathrm{d}_{30}\right)$, diameter at breast height $(\mathrm{dbh})$, and total height of a tree (h). The canopy cover (CC) in two directions (N-S and E-W) was measured and the circular area was calculated. Sample trees were selected subjectively based on 10 classes of dbh. The heartwood diameter $\left(\mathrm{d}_{\mathrm{HW}}\right)$ was measured at a height of $1.30 \mathrm{~m}$ above the ground level of a sampled tree using an increment borer in four directions $(\mathrm{N}, \mathrm{E}, \mathrm{S}$, and $\mathrm{W}$ ) from the stem to avoid bias and error in the determination of heartwood (Romain et al. 2016). The core samples were taken to determine the width of bark, sapwood, and heartwood by differentiating between them based on the color bands (Figure 2).

Disturbed and undisturbed soil samples were taken from at least three different points in each sample plot at two depths, i.e., 0-10 and 10-30 cm. The samples were analyzed in the laboratory for their physical and chemical properties. The measured soil physical properties were particle density, bulk density $\left(\mathrm{g} \mathrm{cm}^{-3}\right)$, porosity $(\%)$, and soil texture $(\%)$. The chemical properties measured were $\mathrm{pH}$ and soil organic matter $(\%)$ (National Soil Survey Center 2014). Climate data were recorded daily at groundbased stations by the plantation staff.

Table 1. Details of the sampled Siamese rosewood plantations in Thailand

\begin{tabular}{lllllll}
\hline Study area & Region & $\begin{array}{l}\text { Precipitation }(\mathbf{m m} \\
\left.\text { year }^{-1}\right)\end{array}$ & Mean Temp. $\left({ }^{\mathbf{0}} \mathbf{C}\right)$ & $\begin{array}{l}\text { Altitude } \\
(\mathbf{m})\end{array}$ & $\begin{array}{l}\text { Spacing } \\
(\mathbf{m})\end{array}$ & $\begin{array}{l}\text { Age } \\
(\mathbf{y e a r s})\end{array}$ \\
\hline PNK & NE & 788 & 26.1 & 296 & $2 \times 4$ & 53 \\
MS & NE & 1,445 & 24.8 & 496 & $4 \times 4$ & 27 \\
NK & NE & 1,555 & 27.0 & 179 & $4 \times 4$ & 24 \\
DL & NE & 1,120 & 26.1 & 317 & $4 \times 4$ & 15 \\
ST & S & 1,019 & 28.2 & 51 & $4 \times 4$ & 27 \\
TK & E & 4,468 & 27.8 & 182 & $4 \times 4$ & 35 \\
KPP & N & 1,262 & 28.5 & 106 & $3 \times 3$ & 30 \\
IT & N & 1,966 & 25.7 & 427 & $6 \times 6$ & 19 \\
RB & W & 1,282 & 27.1 & 222 & $2 \times 4$ & 25 \\
CT & W & 1,074 & 29.9 & 334 & $4 \times 4$ & 17 \\
TPP & W & 1,656 & 27.7 & 129 & $4 \times 4$ & 26 \\
\hline
\end{tabular}




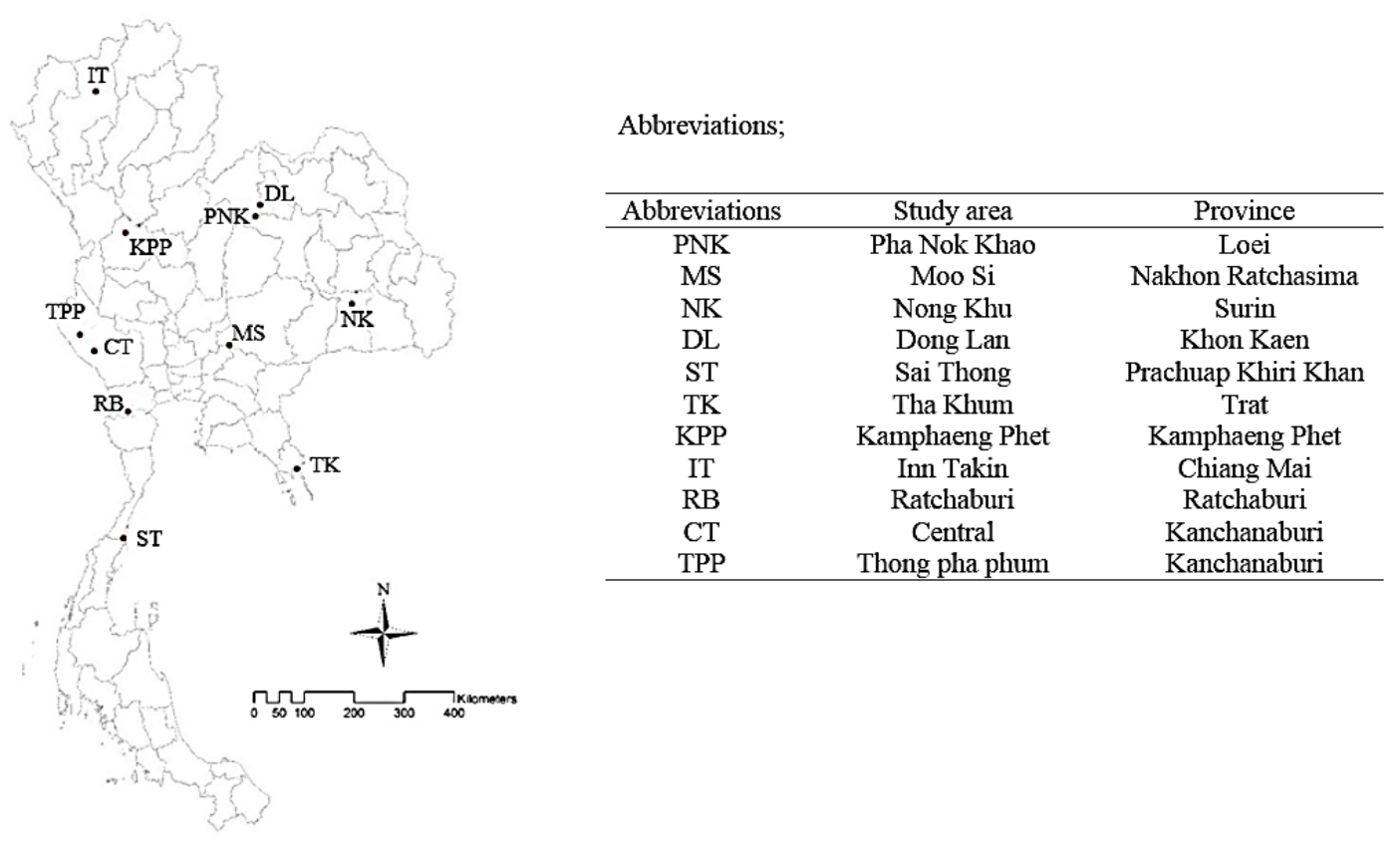

Figure 1. Map of eleven plantations in Thailand that were sampled in this study

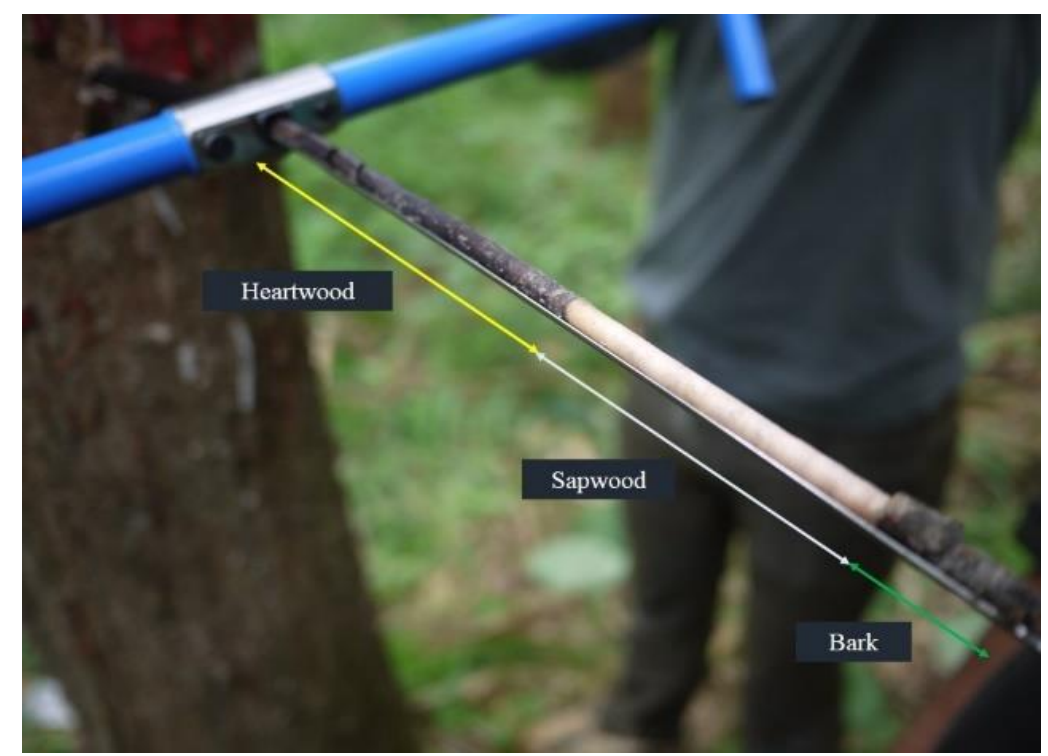

Figure 2. The collection of core sample using an increment borer

\section{Data analysis and calculations}

Non-radial cores and cores not reaching the heartwood were rejected because the models we intended to construct focused on heartwood content. Thereafter, each core sample was calculated as follows:

Canopy cover (CC) was calculated using the canopy diameter measured in the two different directions (N-S and $\mathrm{E}-\mathrm{W}$ as $\mathrm{D}_{1}$ and $\mathrm{D}_{2}$, respectively):

$$
\mathrm{CC}=\pi\left[\left(\mathrm{D}_{1}+\mathrm{D}_{2}\right) / 4\right]^{2}
$$

The mean annual increment (MAI) was calculated as follows:

$$
\mathrm{MAI}=\mathrm{Di} / \text { age of tree }
$$

Where: $D_{i}$ can be either $d_{0}, d_{30}, d b h, d_{H W}$ or height of the trees (diameter measured in $\mathrm{cm}$ year ${ }^{-1}$, height measured in $\left.\mathrm{m} \mathrm{year}^{-1}\right)$.

The heartwood content was estimated using the equation:

$$
\text { Heartwood content }(\%)=\left(\mathrm{HA} \mathrm{BA}_{1.30}\right) \times 100
$$

Where: $\mathrm{HA}=$ heartwood area $\left(\mathrm{cm}^{2}\right)$, and $\mathrm{BA}_{1.30}=$ basal area at a height of $1.30 \mathrm{~m}\left(\mathrm{~cm}^{2}\right)$. 


\section{Data analysis}

The calculated MAI of each tree size parameter $\left(d_{0}, d_{30}\right.$, $\mathrm{dbh}, \mathrm{d}_{\mathrm{HW}}, \mathrm{h}$, and $\mathrm{CC}$ ) across all the sites were compared using a one-way ANOVA and Duncan's multiple range test was used to determine if the differences were significant among the grouped data. Specific environmental factors were used as predictors to estimate the heartwood content by using stepwise multiple regression analysis. The correlations between the heartwood content and all the variables were evaluated. Significant variables were retested using a curve estimation analysis in the $\mathrm{R}$ statistics software package (R Core Team 2020).

\section{RESULTS AND DISCUSSION}

\section{Average size and MAI of Siamese rosewood at various plantations}

The results in Table 2 show the differences among tree parameters due to differences in growth patterns in each sample plot resulting from the individual trees themselves, environmental factors, i.e., climatic and edaphic conditions. Sample trees at PNK (53 years old) had the largest meansized trees as indicated by $\mathrm{d}_{0}, \mathrm{~d}_{30}$, and $\mathrm{dbh}$. On the other hand, DL plantation had the smallest mean-sized as it was the youngest sample tree (15 years old). It was surprising that Siamese rosewood trees planted at TPP plantation (26 years old) had comparable size to trees that were 10 years older at the TK plantation (35 years old). The total height and canopy cover (CC) as a function of tree canopy had similar trends. CC was linked to tree height and survival rate in each stand. Plantations with low survival rates, e.g., DL (23\%) and PNK (16\%), had the highest CC of 31.74 and $49.11 \mathrm{~m}^{2}$, respectively. Therefore, a low tree density results in a larger growing space which promotes canopy expansion and higher growth rate of trees. In other words, wider spacing between trees leads to higher growth rates compared to narrow spacing. However, no significant difference in relation to volume per hectare and stand basal area, and it is possible to obtain the same volume per hectare at the end of the rotation (Denise et al. 2013).
MAI was calculated using both the diameter and height to indicate how quickly can the trees grow during their lifespan. Table 3 shows significantly different results, where $\mathrm{d}_{0}$ ranged between $0.81-1.58 \mathrm{~cm}_{\text {year }}{ }^{-1}, \mathrm{~d}_{30}$ ranged between $0.71-1.41 \mathrm{~cm}$ year $^{-1}$, and $\mathrm{dbh}$ ranged between $0.59-1.06 \mathrm{~cm}$ year $^{-1}$. The highest growth rates were found at the sample plots in DL and TPP plantations, respectively, while the lowest values were found at the NK and PNK plantations. These results indicate that trees that were planted at suitable sites can experience a doubling of growth in diameter, for example, DL compared to PNK plantation. A similar trend was found when comparing the MAI of tree height, with the highest values found at the DL plantation (1.08 $\left.\mathrm{m} \mathrm{year}^{-1}\right)$, which was approximately two times higher when compared with the other stands. The results regarding MAI indicate highly significant differences in the growth rate of trees $(\mathrm{p}<0.01)$.

There are many Dalbergia spp. trees, e.g., D. baronii, D. latifolia, D. melanoxylon, and D. retusa grew in the tropical regions growing across a wide range of environments within various forest types (UNEP-WCMC (2017). Indian rosewood (D. sissoo) is an important timber tree in India (Gilman et al. 2018). It is a fast-growing tree under favorable conditions, especially high rainfall. MAI of $\mathrm{dbh}$ of Indian rosewood planted in India was reported to be between 2.16-2.89 $\mathrm{cm}$ year $^{-1}$ (Rajendran et al. 2019). While, Siamese rosewood is found growing naturally in dry regions. Therefore, MAI of Indian rosewood being approximately 1-3 times higher than that of Siamese rosewood evaluated in this study. However, comparable results were found in Siamese rosewood plantations in Lao PDR, with an MAI calculated from DBH of $0.63 \mathrm{~cm}_{\text {year }}{ }^{-1}$ and from height as being $0.53 \mathrm{~m} \mathrm{year}^{-1}$. Results from the same study reported a survival rate after 6 years of planting of $67.5 \%$ (Phongoudome et al. 2012). As a result of age, DL (15 years old) had a higher growth rate than PNK (53 years old) plantations as estimated from all parameters. Nevertheless, the TPP plantation (26 years old), which was of a comparable age to the NK plantation (24 years old), also had very different MAIs. In spite of this, tree age and site factors are the most important factors influencing the growth rate of Siamese rosewood.

Table 2. Average size of various tree parameters measured at eleven plantations in Thailand

\begin{tabular}{llllllll}
\hline Plantation & $\mathbf{d}_{\mathbf{0}}(\mathbf{c m})$ & $\mathbf{d} \mathbf{3 0}(\mathbf{c m})$ & $\mathbf{d b h}(\mathbf{c m})$ & $\mathbf{h}(\mathbf{m})$ & $\mathbf{C C}\left(\mathbf{m}^{\mathbf{2}}\right)$ & Survival $(\boldsymbol{\%})$ & Age \\
\hline PNK & $42.92 \pm 3.19$ & $37.89 \pm 3.35$ & $31.32 \pm 2.61$ & $22.50 \pm 2.55$ & $49.11 \pm 13.94$ & $16 \pm 1.73$ & 53 \\
MS & $28.80 \pm 1.71$ & $23.30 \pm 0.70$ & $19.50 \pm 0.44$ & $16.76 \pm 0.66$ & $26.40 \pm 5.24$ & $26 \pm 9.30$ & 27 \\
NK & $20.27 \pm 1.83$ & $17.25 \pm 1.71$ & $14.07 \pm 1.49$ & $11.53 \pm 1.70$ & $17.79 \pm 2.30$ & $68 \pm 8.72$ & 24 \\
DL & $23.57 \pm 1.87$ & $21.06 \pm 1.76$ & $15.86 \pm 1.14$ & $16.11 \pm 1.48$ & $31.74 \pm 8.72$ & $23 \pm 6.00$ & 15 \\
ST & $31.84 \pm 1.75$ & $26.00 \pm 0.63$ & $18.10 \pm 0.19$ & $19.97 \pm 0.58$ & $29.31 \pm 0.84$ & $62 \pm 4.04$ & 27 \\
TK & $35.09 \pm 1.61$ & $30.17 \pm 1.43$ & $25.64 \pm 1.51$ & $19.25 \pm 1.35$ & $22.08 \pm 3.43$ & $58 \pm 6.56$ & 35 \\
KPP & $27.40 \pm 0.76$ & $21.09 \pm 1.40$ & $16.74 \pm 0.65$ & $16.73 \pm 0.11$ & $43.62 \pm 2.19$ & $50 \pm 3.61$ & 30 \\
IT & $25.55 \pm 1.24$ & $20.85 \pm 1.70$ & $15.36 \pm 1.45$ & $17.29 \pm 0.36$ & $32.80 \pm 7.89$ & $77 \pm 6.70$ & 19 \\
RB & $29.62 \pm 5.90$ & $26.01 \pm 5.20$ & $22.21 \pm 5.10$ & $13.75 \pm 2.50$ & $53.33 \pm 17.1$ & $54 \pm 8.49$ & 25 \\
CT & $22.62 \pm 0.50$ & $20.46 \pm 0.92$ & $16.56 \pm 1.12$ & $14.99 \pm 0.43$ & $21.85 \pm 4.58$ & $35 \pm 6.56$ & 17 \\
TPP & $37.81 \pm 4.89$ & $33.33 \pm 2.31$ & $24.55 \pm 1.18$ & $20.14 \pm 0.99$ & $64.08 \pm 21.28$ & $28 \pm 2.17$ & 26 \\
\hline
\end{tabular}


Table 3. Mean annual increment (MAI) of Siamese rosewood sampled from eleven plantations in Thailand

\begin{tabular}{|c|c|c|c|c|c|}
\hline Plantations & Age & $d_{0}\left(\mathrm{~cm} \mathrm{year}^{-1}\right)$ & $d_{30}\left(\mathrm{~cm}_{\text {year }}{ }^{-1}\right)$ & dbh $\left(\mathrm{cm}\right.$ year $\left.^{-1}\right)$ & H $(\mathrm{m}$ year-1) \\
\hline PNK & 53 & $0.81 \pm 0.06^{\mathrm{f}}$ & $0.71 \pm 0.06^{\mathrm{e}}$ & $0.59 \pm 0.05^{\mathrm{f}}$ & $0.43 \pm 0.05^{f}$ \\
\hline MS & 27 & $1.07 \pm 0.06^{\mathrm{de}}$ & $0.86 \pm 0.03^{\mathrm{de}}$ & $0.72 \pm 0.02^{\mathrm{def}}$ & $0.62 \pm 0.02^{\mathrm{d}}$ \\
\hline NK & 24 & $0.84 \pm 0.08^{\mathrm{f}}$ & $0.72 \pm 0.07^{\mathrm{e}}$ & $0.59 \pm 0.06^{\mathrm{f}}$ & $0.48 \pm 0.07^{\mathrm{ef}}$ \\
\hline DL & 15 & $1.58 \pm 0.11^{\mathrm{a}}$ & $1.41 \pm 0.10^{\mathrm{a}}$ & $1.06 \pm 0.08^{\mathrm{a}}$ & $1.08 \pm 0.08^{\mathrm{a}}$ \\
\hline ST & 27 & $1.18 \pm 0.06^{\mathrm{cde}}$ & $0.96 \pm 0.02^{\mathrm{cd}}$ & $0.67 \pm 0.01^{\mathrm{ef}}$ & $0.74 \pm 0.02^{c}$ \\
\hline TK & 35 & $1.00 \pm 0.05^{\mathrm{ef}}$ & $0.86 \pm 0.04^{\mathrm{de}}$ & $0.73 \pm 0.04^{\mathrm{def}}$ & $0.55 \pm 0.04^{\mathrm{de}}$ \\
\hline KPP & 22 & $1.25 \pm 0.03^{\mathrm{cd}}$ & $0.96 \pm 0.06^{\mathrm{de}}$ & $0.76 \pm 0.03^{\mathrm{cde}}$ & $0.76 \pm 0.01^{\mathrm{c}}$ \\
\hline IT & 19 & $1.34 \pm 0.06^{\mathrm{bc}}$ & $1.10 \pm 0.09^{b c}$ & $0.81 \pm 0.08^{\text {bcde }}$ & $0.91 \pm 0.02^{b}$ \\
\hline $\mathrm{RB}$ & 25 & $1.18 \pm 0.24^{\mathrm{cde}}$ & $1.04 \pm 0.21^{\mathrm{cd}}$ & $0.89 \pm 0.20^{\mathrm{bc}}$ & $0.45 \pm 0.08^{f}$ \\
\hline $\mathrm{CT}$ & 20 & $1.13 \pm 0.03^{\mathrm{de}}$ & $1.02 \pm 0.05^{\mathrm{cd}}$ & $0.83 \pm 0.06^{\mathrm{bcd}}$ & $0.75 \pm 0.02^{c}$ \\
\hline TPP & 26 & $1.45 \pm 0.19^{\mathrm{ab}}$ & $1.29 \pm 0.29^{\mathrm{ab}}$ & $0.94 \pm 0.05^{\mathrm{ab}}$ & $0.77 \pm 0.04^{\mathrm{c}}$ \\
\hline Significant & & $* *$ & ** & ** & *** \\
\hline$P$-value & & $<0.01$ & $<0.01$ & $<0.01$ & $<0.01$ \\
\hline
\end{tabular}

Note: ${ }^{* *}$ indicating a highly significant difference at a level of $\mathrm{p}<0.01$

Table 4. Heartwood content and MAI in Siamese rosewood trees sampled from eleven plantations in Thailand

\begin{tabular}{llll}
\hline Plantations & $\begin{array}{c}\text { Heartwood } \\
\text { content } \\
(\%)\end{array}$ & $\begin{array}{c}\text { MAI of heartwood } \\
\text { diameter } \\
(\mathbf{c m} \text { year }\end{array}$ & Age \\
\hline PNK & $72.10 \pm 5.50^{\mathrm{a}}$ & $0.42 \pm 0.15$ & 53 \\
MS & $68.30 \pm 13.54^{\mathrm{a}}$ & $0.64 \pm 0.20$ & 27 \\
NK & $41.11 \pm 18.50^{\mathrm{b}}$ & $0.31 \pm 0.22$ & 24 \\
DL & $32.18 \pm 18.60^{\mathrm{bc}}$ & $0.50 \pm 0.50$ & 15 \\
ST & $44.12 \pm 22.55^{\mathrm{b}}$ & $0.49 \pm 0.43$ & 27 \\
TK & $63.29 \pm 14.14^{\mathrm{a}}$ & $0.46 \pm 0.23$ & 35 \\
KPP & $35.34 \pm 21.49^{\mathrm{bc}}$ & $0.34 \pm 0.29$ & 30 \\
IT & $21.87 \pm 16.33^{\mathrm{c}}$ & $0.29 \pm 0.24$ & 19 \\
RB & $42.44 \pm 20.46^{\mathrm{b}}$ & $0.57 \pm 0.29$ & 25 \\
$\mathrm{CT}$ & $31.15 \pm 16.11^{\mathrm{bc}}$ & $0.39 \pm 0.36$ & 17 \\
TPP & $41.92 \pm 27.89^{\mathrm{b}}$ & $0.58 \pm 0.55$ & 26 \\
Significant & $* *$ & ns & \\
$P$-value & $<0.01$ & $\geq 0.05$ & \\
\hline \multicolumn{2}{l}{ Note: ${ }^{* *}$ indicating a highly significant difference at $\mathrm{p}<0.01$ level, } \\
ns non-significant difference at a level of $\mathrm{p}>0.05$. Different letters \\
in the same row refer to significant differences $(\mathrm{p}<0.05)$
\end{tabular}

\section{Heartwood content and MAI of heartwood}

The heartwood content estimated in the present study was quantified by using the proportion of heartwood per stem basal area at a height of $1.30 \mathrm{~m}$ from the ground level. The results indicate highly significant differences in MAI between plantations. We estimated the highest heartwood content at the PNK, MS, and TK plantations with 72.10 , 68.30 , and $63.29 \%$, respectively. In contrast, only $21.87 \%$ heartwood was found at the IT plantation, as the trees were very young. These numbers are considerably lower than what has been calculated for natural forests of unknown age, the volume of heartwood of Indian rosewood varied significantly within different climatic zones, and ranged from 76.03-79.36\% (Rishi and Sidhu 2002).

Heartwood content was positively correlated with the dbh and very much an age-related process. The larger heartwood of Indian rosewood are produced from rotations of 40-60 years (CABI, 2013). The study by Sellin (1996) indicated that the heartwood volume is cumulative, whereas the sapwood area is not. Thus, the content of heartwood within a stem increases with tree age. The slow growth of D. baronii taking 70-100 years to yield sufficient heartwood for felling (Ramananantoandro et al. 2013). For other species, the heartwood proportions of Teak (Tectona grandis) varied with the crown class, with estimations for dominant, mean, and suppressed trees being 60\%, 55\%, and 51\%, respectively (Yang et al. 2020). Vicelina et al. (2012) revealed that Teak heartwood accounted for $66-90 \%$ of the stem radius. Heartwood percentage of Santalum macgregorii was $15.8 \%$, with no significant differences between sites. A positive correlation was found between stem and heartwood diameter (Page et al. 2020). The mean heartwood percentage of Indian sandalwood ( $S$. album) trees at ground level $(0 \mathrm{~m})$ were $19.2 \%$, and then continued to decrease up the tree to only $2.8 \%$ at $3.00 \mathrm{~m}$ (Jonathan et al. 2012).

Many arguments support the conclusion of the present study that older trees have a higher probability of receiving stains, a significant factor determining the proportion of heartwood. The increment in heartwood diameter of 27 years old trees at the MS plantation was the highest $(0.64$ $\mathrm{cm} \mathrm{year}^{-1}$ ) with the lowest value estimated for the IT, a 19 years old plantation, at $0.29 \mathrm{~cm}_{\text {year }}{ }^{-1}$. The results had an insignificant difference $(p \geq 0.05)$ for the increment in heartwood diameter. Thus, this indicates that similar heartwood content is produced by similarly sized of trees. Other factors affecting the formation of heartwood have been shown to be controlled genetically, e.g., in Eucalyptus cladocalyx (Bush et al. 2011). Regardless of this study, all plantations are planted with seedlings sourced from unknown seed banks. As a result, the genetic variations are hard to be accounted for. Therefore, we did not focus on the genetic factors in the present study.

\section{Estimation of heartwood content}

The tree measurements, such as $\mathrm{d}_{0}, \mathrm{~d}_{30}, \mathrm{dbh}$, height, and $\mathrm{CC}$, were used as predictive variables to estimate the heartwood content by using a multiple regression analysis. The prediction model of heartwood content contain an inherently higher amount of unexplainable variability. However, the results showed that $\mathrm{dbh}$ is the most relevant 
variable to estimate the percentage of heartwood, as determined by the following equation;

Heartwood content $(\%)=6.132+1.66 \times \mathrm{dbh}, \mathrm{R}^{2}=0.477$; $\mathrm{SE}=17.248$

Heartwood content was found to be positively influenced by tree growth. We observed a general increasing trend of heartwood content with increasing tree diameter. A linear relationship between heartwood content and tree size was found. The results estimated from our equation explain that a tree has a chance of having a higher heartwood content when it has a larger diameter. This was concluded based on a positive correlation between the heartwood content and dbh. For this reason, a younger tree that is in the same dbh class as an older tree, means faster growth rate. This faster-growing tree might have a larger heartwood content. Tree diameter (dbh) as a predictor in the model was resulted of age. Therefore, tree age was positively correlated with the proportion of heartwood content when used as a predictor variable in the model. The correlation between these two factors can cause issues with interpretation of results, but once dbh was introduced, age was not a significant factor (Kaminski et al. 2019). Many studies reported that dbh was the most commonly used and the most effective variable for estimating heartwood volume in many tree species (Yang et al. 2020). Regression equations, relating age to the amount of heartwood, have been developed for various species, e.g., Indian rosewood (Pande 2013) and Teak (Moya et al. 2020).

Moreover, we tried to determine the relationship between certain environmental factors affecting the heartwood content in Siamese rosewood by using multiple regression analysis. The results show that heartwood content is strongly dependent on the soil conditions ( $\mathrm{p}<$ 0.01) measured through three soil parameters, i.e., soil particle density (DP) $\left(\mathrm{g} \mathrm{cm}^{-1}\right)$, soil organic matter (OM), and silt particles $(\%)$ in the topsoil layer $(0-10 \mathrm{~cm})$. The multiple regression model for predicting heartwood content (\%) with the most important environmental variables $\left(\mathrm{R}^{2}=\right.$ 0.843 ) can be mathematically written as;

$$
\begin{gathered}
\text { Heartwood content }(\%)=240.681+(-66.367 \times \mathrm{DP}) \\
+(-7.535 \times \mathrm{OM})+(-1.844 \times \text { Silt })
\end{gathered}
$$

The variation in the heartwood content is affected by site, geographic location, and environmental conditions (Moya et al. 2014). Soil properties also affect the growth of trees, e.g., Jennifer et al. (2020) observed strong positive relationships between soils with higher clay content serve to high tree growth in tropical forests by avoiding phosphorus losses from the ecosystem. In this study, it was found that DP, OM, and silt percentage had an inverse relationship with the heartwood content. In addition, the results indicate that the heartwood content of Siamese rosewood is significantly related to the properties of topsoil layer. This is similar to the findings of Naranjo et al. (2012), who reported that the physical and chemical properties of subsoil did not affect the amount of heartwood contained in trees. Bektas et al. (2003) reported that heartwood ratios of Turkish Calabrian pine (Pinus brutia) could be attributed to lime and organic material content of the soil, along with the soil type. By contrast, soil $\mathrm{pH}$ and percent sand were found to have no significant effect on the proportion of heartwood in Sugar maple (Acer saccharum) (Kaminski et al. 2019). Heartwood content might be related to climatic factors as indicated by the content in Eucalyptus urophylla, which had a strong relationship with the climate factors (Maria and Baptista 2020).

In conclusion, environmental factors, such as soil properties and some climate variables, can be used as predictors for estimating the heartwood content in some species like Indian rosewood, which is strongly dependent on the soil conditions (Casadei and Albert 2015). From the results of this study, we conclude that larger trees have a higher heartwood content than smaller trees. The growth rate of Siamese rosewood was comparable to other commercial tree species growing in the tropical region. Furthermore, these results indicate that Siamese rosewood plantations located in suitable sites could experience a doubling of growth. This observation is of great significance for improving the management of plantations, for example in terms of appropriate thinning and fertilization to promote stem growth and thus accelerate the formation of heartwood or to harvest in longer rotation cycles. Siamese rosewood does not appear to be an appropriate choice in plantations across all of Thailand. But understanding the environmental demands of this species could be used during the decision-making process before establishing an economically viable plantation. An economic analysis of Siamese rosewood plantations would be needed to determine the productivity of such plantations.

\section{ACKNOWLEDGEMENTS}

This work was funded by the Kasetsart University Research and Development Institute (KURDI) and OPORA program of Faculty of Forestry, Kasetsart University, Thailand. We are also grateful for all the support and a friendly working environment with the research participants at the Faculty of Forestry, Kasetsart University, Royal Forest Department and Forest Industry Organization (FIO), Thailand.

\section{REFERENCES}

Bektas I, Hakki A, Yener G, Alaaddin Y, Recep G. 2003. Influence of site on sapwood and heartwood ratios of Turkish Calabrian pine. For Prod J 53 (4): 48-50.

Bush D, Kevin M, Roger M. 2011. Genetic variation of natural durability traits in Eucalyptus cladocalyx (Sugar gum). Ann For Sci 68 (6): 1057-1066. DOI: 10.1007/s13595-011-0121-z.

CABI. 2013. Dalbergia sissoo; invasive species compendium. http://www.cabi.org/isc/datasheet/17808.

Casadei E, Albert J. 2015. Encyclopedia of Food and Health. Food and Agriculture Organization of the United Nations (FAO), Rome.

CITES. 2013. Dalbergia cochinchinensis is proposed for listing in Appendix II of CITES in accordance with Article II paragraph 2(a) of the Convention and Resolution Conf. 9.24 (Rev. CoP15) Annex 2 (a) 
Paragraph A. The $16^{\text {th }}$ meeting of the Conference of the Parties, Bangkok, 3-14 March 2013.

CITES. 2014. Trade in Siamese rosewood (Dalbergia Cochinchinensis) from Thailand. The Convention on International Trade in Endangered Species of Wild Fauna and Flora (CITES), Geneva.

Denise JC, André EBL, Maria ADR, Marilice CG, Renato TL. 2013. Influence of spacing regimes on the development of loblolly pine (Pinus taeda L.) in Southern Brazil. For Ecol Manag 310: 761-769. DOI: 10.1016/j.foreco.2013.09.021.

EIA. 2014. Routes of extinction: the corruption and violence destroying Siamese rosewood in the Mekong. Environmental Investigation Agency (EIA), UK.

Gilman EF, Dennis GW, Ryan WK, Andrew KK, Deborah RH, Drew CM. 2018. Dalbergia Sissoo: Indian rosewood. U.S. Department of Agriculture, Washington, DC.

Inthacha S. 2011. Washington, DCThe Climatology of Thailand and Future Climate Change Projections using The Regional Climate Model Precis. [Dissertation]. University of East Anglia, Norwich, UK.

IUCN.

$$
2021 .
$$

Siamese

rosewood. https://www.iucn.org/sites/dev/files/import/downloads/dalbergia_coc hinchinensis.pdf

Jennifer LS, Ivan AJ, Oriol G, Olga M, Clément S, Leandro VL, Ifigenia U, Jerome C, Aurelie D, Bruno F, Vincent F, Bruno H, Jordi S, Josep P, Erik V. 2020. Soil properties explain tree growth and mortality, but not biomass, across phosphorus-depleted tropical forests. Sci Rep 10 (1): 1-4. DOI: 10.1038/s41598-020-58913-8.

Jonathan EB, Len JN, Ian CD. 2012. Estimated heartwood weights and oil concentrations within 16-year-old Indian sandalwood (Santalum album) trees planted near Kununurra, Western Australia. Aust For 75 (4): 225-232. DOI: 10.1080/00049158.2012.10676406.

Kaminski J, Michael D, Nilesh T. 2019. Factors relating to dark heart of Sugar maple in Wisconsin. J For 117 (3): 256-266. DOI: 10.1093/jofore/fvz013.

Liu J, Wang C, Zhang Q. 2014. Spatial variations in stem heartwood and sapwood for Larix gmelinii trees with various differentiation classes. Sci Silvae Sin 50 (12): $114-121$. DOI: $10.11707 / \mathrm{j} / 1001$ 7488.2014216

Maria V, Baptista G. 2020. Heartwood variation of Eucalyptus urophylla is influenced by climatic conditions. For Ecol Manag 458: 1-10. DOI 10.1016/j.foreco.2019.117743.

Moya R, Gaitán-Álvarez J, Ortiz-Malavassi E, Berrocal A, FernándezSólis D. 2020. Equations for predicting heartwood merchantable volume and tradable sawlog in Tectona grandis. J Trop For Sci 32 (4): 379-390. DOI: $10.26525 / \mathrm{jtfs} 2020.32 .4 .379$

Moya R, Brian B, Henry Q. 2014. A review of heartwood properties of Tectona grandis trees from fast-growth plantations. Wood Sci Technol 48 (2): 411-433. DOI: 10.1007/s00226-014-0618-3.

Naranjo SS, Moya R, Chauhan S. 2012. Early genetic evaluation of morphology and some wood properties of Tectona grandis L. clones. Silvae Genet 61 (1-2): 58-65. DOI: 10.1515/sg-2012-0008.

National Soil Survey Center. 2014. Kellogg Soil Survey Laboratory Methods Manual. United States Department of Agriculture, Washington DC.

Page T, Jeffrey GK, Macdonell P, Hettiarachchi D, Boyce MC, Lata A, Oa L, Rome G. 2020. Morphological and heartwood variation of
Santalum macgregorii in Papua New Guinea. Aust For 83 (4): 195207. DOI: $10.1080 / 00049158.2020 .1841440$.

Pande PK. 2013. Influence of growth, wood anatomical properties and specific gravity on heartwood, sapwood and tension-wood in Dalbergia sissoo Roxb. J Indian Acad Wood Sci 10 (1): 16-21. DOI: 10.1007/s13196-013-0087-6.

Phongoudome C, Lee DK, Silavanh S, Marilyn SC, Wai MH. 2012. Biomass and carbon content allocation of six-year-old Anisoptera costata Korth., and Dalbergia cochinchinensis Pierre, plantations in Lao PDR. J Agric Res Man 259: 1-14. DOI: 10.7237/sjarm/259.

Phunchaisri T, Chongrak W, Ponthep M, Suwan T, Nawaphong K. 2020. Site index of Siamese rosewood (Dalbergia cochinchinensis Pierre) in plantation of Thailand. Biotropia 27 (2): 162-170. DOI: 10.11598/btb.2020.27.2.1199.

$\mathrm{R}$ Core Team. 2020. The $\mathrm{R}$ project for statistical computing. https://www.r-project.org.

Rajendran P, Arunmaharaja B, Krishnakumar N, Parthiban KT. 2019. Clonal variation of Dalbergia sissoo genetic resources. J Pharm Innov 8 (11): 271-277.

Ramananantoandro T, Ramanakoto MF, Rajemison AH, Eyma F. 2013. Relationship between density and aesthetic attributes of wood and preference of Malagasy consumers. Ann For Sci 70 (6): 649-658. DOI: $10.1007 / \mathrm{s} 13595-013-0299-3$.

Rishi LB, Sidhu DS. 2002. Effect of environment on heartwood amount in Dalbergia sissoo Roxb. in different climatic zones of Punjab. Indian For 128 (7): 779-785.

Romain L, Hélène M, Julie B, Gilles M, Nadine A, Jacques B, Eric N. 2016. Heartwood/sapwood profile and the tradeoff between trunk and crown increment in a natural forest: the case study of a tropical tree (Dicorynia guianensis Amsh., Fabaceae). Trees 31 (1): 199-214. DOI: 10.1007/s00468-016-1473-7.

Sellin A. 1996. Sapwood amount in Picea abies (L.) Karst. determined by tree age and radial growth rate. Holzforschung 50: 291-296. DOI: 10.1515/hfsg. 1996.50.4.291.

Treanor NB. 2015. Hongmu consumption boom: Analysis of the Chinese rosewood trade and links. https://www.forest-trends.org/wpcontent/uploads/imported/for173-china-rosewood-report-letter-160329-hr-no-crops-pdf.pdf

UNEP-WCMC. 2017. Review of selected Dalbergia species and Guibourtia demeusei. The United Nations Environment's World Conservation Monitoring Centre, Cambridge.

United Nations. 2015. Rosewood logs. United Nations Office on Drugs and Crime, Rome.

Vicelina BS, Sofia C, Teresa Q, Helena P. 2012. Growth rate and ring width variability of teak, Tectona grandis (Verbenaceae) in an unmanaged forest in East Timor. Rev Biol Trop 60 (1): 483-494. DOI: $10.15517 /$ rbt.v60i1.2783.

Xu FZC. 2016. Identification of Dalbergia cochinchinensis (CITES Appendix II) from other three Dalbergia species using FT-IR and 2D correlation IR spectroscopy. Wood Sci Technol 50 (4): 693-704. DOI: 10.1007/s00226-016-0815-3.

Yang B, Hongyan J, Zhigang Z, Shengjiang P, Daoxiong C. 2020. Horizontal and vertical distributions of Heartwood for Teak plantation. Forests 11 (2): 225. DOI: 10.3390/f11020225. 